DOI: 10.17117/na.2016.08.01.035

http://ucom.ru/doc/na.2016.08.01.035.pdf

Поступила (Received): 25.08.2016

\title{
Гарипова В.В.
}

\section{Направления совершенствования процесса формирования доходов бюджетов муниципальных образований в РФ}

\author{
Garipova V.V. \\ Directions of perfection of process of formation of \\ incomes of budgets of municipal formations in Russia
}

Местный бюджет - один из главных каналов доведения до населения конечных результатов производства. Через них общественные фонды потребления распределяются между отдельными группами населения. В статье предложены направления совершенствования процесса формирования доходов бюджетов муниципальных образований

Ключевые слова: бюджет, налоги, местный бюджет

\section{Гарипова Венера Валериевна}

Кандидат экономических наук, доцент

Казанский инновационный университет им. В.Г.

Тимирясова

2. Казань, ул. Московская, 42

\begin{abstract}
The local budget is one of the main channels for informing the public of the final results of production. Through them, the public consumption funds are distributed among separate groups of the population. The article offered directions of perfection of process of formation of incomes of budgets of municipalities
\end{abstract}

Key words: budget, taxes, local budget

\section{Garipova Venera Valerievna}

Candidate of Economic Sciences, Associate Professor Kazan innovative university named V.G. Timiryasov Kazan, Moskovskaya st., 42

Для укрепления самостоятельности местных бюджетов целесообразно закрепить за ними стабильные налоговые источники, в частности, увеличив долю НДФЛ, зачисляемую в местные бюджеты.

Минимальный размер отчислений от НДФЛ необходимо увеличить до 30 - 40 \%, учитывая, что реализация расширившегося в последние несколько лет перечня вопросов местного значения повлекла увеличение расходов местных бюджетов на их осуществление. Это усугубило проблему несбалансированности бюджетов муниципальных образований и ограничило возможности органов местного самоуправления эффективно решать другие вопросы местного значения [аветисян].

Необходимо, сохранив статус НДФЛ как федерального налога, предоставить право субъектам РФ устанавливать отдельные элементы налогообложения по налогу на доходы физических лиц:

- налоговую базу; 
- порядок исчисления и уплаты налога;

- круг налогоплательщиков;

- налоговые льготы.

Часто также критикуется и механизм распределения НДФЛ между бюджетами субъектов Российской Федерации, так как возникает проблема определения того бюджета, в который должны зачисляться поступления по налогу.

Уже несколько лет продолжаются споры о целесообразности введения в законодательство положения о зачислении налога на доходы физических лиц по месту жительства налогоплательщика.Работая и уплачивая НДФЛ на территории одного муниципального образования, люди проживают на территории другого, пользуясь при этом всей его социальной и прочей инфраструктурой.

В таких условиях возникает вопрос о целесообразности переноса уплаты данного налога по месту жительства налогоплательщика. По мнению ряда экспертов, установление порядка зачисления сумм налога в бюджет по месту жительства плательщика может дать существенные положительные результаты. В частности, способствовать тому, что территория улучшит свое финансовое планирование за счет большего соответствия объемов планируемых расходов на социальную сферу и инфраструктурные проекты прогнозируемым доходам. Кроме того, это позволит упростить порядок предоставления имущественных налоговых вычетов по НДФЛ, так как вычеты будут предоставляться из того же бюджета, в который поступает НДФЛ, и дополнительных расчетов между бюджетами по возмещению вычетов не потребуется.

Однако есть и противники введения такого порядка уплаты налога, которые выдвигают контраргументы. Они говорят о том, что необходимо развивать бизнес, создавать рабочие места и улучшать условия труда на собственной территории, а не способствовать утечке рабочей силы в соседние регионы. Не следует забывать также и о том, что и регионы - реципиенты рабочей силы несут дополнительные затраты по развитию социальной и прочей инфраструктуры, которая используется в том числе гражданами, не проживающими, но работающими на данной территории, а также решают проблемы соседей в части обеспечения их населения рабочими местами и доходными источниками.

Не следует забывать и о том, что введение уплаты НДФЛ по месту жительства ныне сопряжено с рядом трудностей: проблемы могут возникнуть как в администрировании поступления налога налоговыми органами, так и в отношении расчета и уплаты налога налоговыми агентами в связи с необходимостью ведения дополнительного учета налогоплательщиков по месту жительства.

Все это препятствует формированию однозначной позиции о целесообразности введения нового порядка зачисления НДФЛ по месту жительства налогоплательщиков.

Также очень часто органами местного самоуправления поднимается вопрос о необходимости изменения структуры распределения доходов от НДФЛ по уровням бюджетной системы и повышения доли поступлений НДФЛ, зачисляемой в местный бюджет, до 70\%.

Еще одним обсуждаемым и весьма неоднозначным является вопрос о возможности введения прогрессивной шкалы налогообложения доходов граждан. 
В истории налогообложения современной России практика прогрессивного подоходного налогообложения уже была.

Однако такая система не была признана эффективной, что во многом было связано с применением налогоплательщиками различных схем занижения величины полученных доходов с целью применения более низкой ставки подоходного налога. Сторонники пропорционального налогообложения говорят о том, что пропорциональная ставка обеспечивает справедливый характер налогообложения: сумма налога изменяется соответственно изменению суммы дохода.

Таким образом, задача повышения самостоятельности местных бюджетов требует принятия определенных мер, наиболее действенными из которых могут стать следующие:

- повышение норматива зачисления НДФЛ в местные бюджеты;

- придание определенной доли самостоятельности субъектам РФ в части установления отдельных элементов налогообложения НДФЛ;

- более детальная проработка вопросов предоставления налоговых льгот по НДФЛ с компенсацией местным бюджетам недополученных доходов в результате действия общефедеральных льгот.

Все это позволит создать условия для роста доходной базы муниципальных бюджетов и будет способствовать повышению эффективности деятельности органов местного самоуправления, их ответственности за принимаемые решения в финансовой сфере.

Важнейшим перспективным источником расширения доходной базы местных бюджетов является совершенствование системы имущественных налогов, которые в соответствии с мировой практикой должны быть местными налогами. И тут основным направлением должна стать модернизация местных налогов.

Для увеличения поступлений по земельному налогу необходимо:

- в целях снижения дотационности заменить прямые дотации муниципалитетам поступлениями от земельного налога на землю, находящуюся в государственной собственности;

- за земельные участки, на которых долгое время не проводятся сельскохозяйственные работы, следует взимать повышенную ставку земельного налога. Это предложение требует внесения дополнений в ст. 85 части первой Налогового кодекса РФ, где определяется порядок обращения органов государственной власти, отвечающих за земельный надзор, в налоговую инспекцию для предоставления сведений о "простаивающих без дела" или занятых большими строениями земельных участках сельскохозяйственного назначения.

В целях укрепления налоговой базы, создания долгосрочных стимулов к развитию территорий необходимо предоставить местным органам власти права по регулированию всех элементов по местным налогам. Это обеспечит конституционные права и реальную самостоятельность муниципалитетов в формировании финансовой базы. 
В целях преодоления последствий финансового кризиса, сокращения дотационности муниципальных образований и укрепления их финансовой самостоятельности за местными бюджетами необходимо закрепить фиксированную долю отчислений от транспортного налога (в целях расширения финансовых возможностей муниципальных образований по формированию муниципальных дорожных фондов в составе местных бюджетов).Это позволит решать вопросы содержания и строительства транспортных инженерных сооружений в границах муниципального образования, которые являются прямыми его полномочиями.

Поскольку налог на доходы физических лиц является основополагающим доходным источником муниципального образования, предлагается внести изменения в Налоговый кодекс РФ, предусмотрев его уплату по месту жительства налогоплательщика, так как основные социальные услуги граждане получают, как правило, по месту жительства (образование, здравоохранение, благоустройство и др.).

Принципиально важно, чтобы в местные бюджеты поступали налоги, выплачиваемые предприятиями, в первую очередь предприятиями малого и среднего бизнеса. Это позволит заинтересовать органы местного самоуправления в поддержке предпринимательства на соответствующих территориях, станет мощным стимулом для органов местного самоуправления по развитию экономики. На местном уровне можно более эффективно учитывать многие особенности и специфику деятельности субъектов малого и среднего бизнеса на соответствующих территориях, эффективно применять к ним те или иные механизмы налогообложения.

\section{Список используемых источников:}

1. Аветисян И.А. Вопросы государственного регулирования процессов распределения и использования в современной России // Экономические и социальные перемены в регионе: факторы, тенденции, прогноз. 2012. №1(5). С. 107-122.

2. Мудрова Н.В. Актуальные проблемы формирования доходов местных бюджетов // Финансы. 2014. № 3. C. 25-30.

3. Смородинов М. Налог на имущество начнут считать по-новому // Жилищное право. 2013. №1.

C. $108-112$.

\section{(C) 2016, Гарипова В.В.}

Направления совершенствования процесса формирования доходов бюджетов муниципальных образований в РФ
(C) 2016, Garipova V.V.

Directions of perfection of process of formation of incomes of budgets of municipal formations in Russia 